\title{
Cost-benefit analysis of a nationwide neonatal inoculation programme against hepatitis $B$ in an area of intermediate endemicity
}

\author{
Gary M Ginsberg, Daniel Shouval
}

\begin{abstract}
Study objective-The aim was to estimate the costs and benefits of a nationwide neonatal vaccination campaign against hepatitis $B$ in Israel for the 1990-2034 period.

Design-Using morbidity, mortality, utilisation, and cost data from Israeli and international sources, a spreadsheet model was constructed to carry out the cost-benefit analysis.

Setting-The entire State of Israel, an area of intermediate endemicity.

Participants-The population of Israel from 1990-2034.

Main results $-A$ policy of immunising all Israeli neonates would, for a cost of $\$ 13.8$ million, reduce the number of cases of hepatitis $B$ during the $1990-2035$ period in the cohort from 359000 to 166000 and save the nation around $\$ 21.5$ million in health resources alone, $\$ 16.6$ million in averted work absences, and a further $\$ 0.6$ million in averted premature mortality costs. Even when the savings to the health services (\$0.6 million) arising from the reduction in hepatocellular carcinoma are excluded, the direct benefit to cost ratio is $1 \cdot 51 / 1$, still in excess of unity.

Conclusions-The decision to adopt a nationwide neonatal inoculation policy, starting in January 1992, appears to be not only medically but also economically justifiable.
\end{abstract}

f Epidemiol Community Health 1992; 46: 587-594

Hepatitis B virus (HBV) infection is a major health hazard worldwide. It is estimated that between 200 and 300 million people are hepatitis B surface antigen (HBsAg) carriers. ${ }^{1-3}$ Persons at increased risk in industrialised nations are those whose occupation, illness, or behavioural habits bring them into frequent contact with blood, blood products, ${ }^{45}$ or possibly other body fluids. Such persons include health service workers, homosexuals, parenteral drug misusers, and prisoners. The morbidity and mortality of acute and chronic hepatitis B virus infection generate not only considerable direct health care costs, but also substantial indirect costs in terms of premature mortality costs and costs of days lost from work.

Available hepatitis B vaccines are safe and effective in preventing infection in adults, ${ }^{67}$ children, ${ }^{8}$ and infants at risk. ${ }^{9}$ A recent study reported the virtual elimination (a decrease in incidence of $99^{\circ}{ }_{0}$ ) of hepatitis B transmission over a five year period in persons of all ages as the result of widespread use of hepatitis $B$ vaccine in remote
Alaskan Eskimo villages. ${ }^{10} 11$ Arevalo and Washington $^{12}$ found that routine screening of pregnant women (with subsequent inoculation) in the USA would be cost-effective at a disease prevalence rate of $0.06^{\circ}$, well below the national prevalence rate in the USA of $0 \cdot 2^{\circ}{ }_{0}$. A national policy of routine screening for all pregnant women would result in net savings in excess of $\$ 105$ million per annum.

By November 1989, 23 of the 35 countries and areas in the WHO's Western Pacific region had started hepatitis B immunisation of newborn children $^{13}$; nine more were expected to start in 1990.

Up to January 1991 in Israel, hepatitis B vaccination has been offered only to hospital and laboratory workers. Screening and vaccination of neonates is carried out in only a few of the country's 36 general hospitals. The cost of hepatitis $B$ vaccines has been declining rapidly since recombinant vaccines have replaced serum derived vaccines, falling from $\$ 100$ for three paediatric doses (including cold chain and administration costs ${ }^{14}$ ) in 1980 to approximately $\$ 2.80$ in $1989 .{ }^{15}$ This huge decrease in costs prompts an examination of the feasibility of a nationwide neonatal vaccination campaign.

This paper will present a cost-benefit analysis of a nationwide neonatal immunisation programme against hepatitis B for the 1990-2035 period. The model analysed uses methodology developed by Mulley et $a l^{14}$ and sometimes relies on data adapted from studies in other countries, as not all the relevant data are available from the Israeli population.

The incremental costs and benefits of the vaccination strategies will take into account changing needs for ambulatory care, hospital admissions, work absences, and mortality benefits from projected reductions in acute hepatitis and its sequelae: chronic active hepatitis, cirrhosis, and primary hepatocellular carcinoma. ${ }^{16-23}$

\section{Methods \\ DATA \\ Notifications (reported cases)}

Viral hepatitis cases are reported individually, based on clinical diagnosis with or without laboratory confirmation by the attending physician, clinic, hospital, or other health care institution. Data are collected in the epidemiology department and public health divisions of the Ministry of Health. In January 1992, cases began to be reported with classification given to the type of hepatitis $(A, B$, non $A-$ non $B)$, instead of under the general heading of hepatitis.

In Israel, an average of 3666 cases and 13.1 deaths from acute viral hepatitis were reported 
annually during the period $1971-1985 .{ }^{24-26} \mathrm{How}-$ ever in reality the total number of hepatitis virus infections in general and hepatitis B in particular is underestimated. As with most infectious diseases, there is considerable underreporting. Estimates of the reporting rate include those by Reisler et $a l^{27}(27 \%-39 \%)$, Schwartz et al 28 $(27 \%-56 \%)$, Kark and Bar Shani ${ }^{29}(33 \%$ to $50 \%)$, Green et al $30(40 \%-60 \%)$, and Fattal $(41.2 \%)^{31}$, the latter estimate based solely on a Kibbutz population. In our calculations we used a figure of $33.33 \%$, based on the results found by Eliakim $^{32}$ in a study using ambulatory records. A similar rate $(33 \%)$ has been found in (west) Germany. $^{8}$

During the period 1971-1985, seroepidemiological studies indicated wide variations in the rates of hepatitis $B$ infection between sexes and differing ethnic groups in Israel. ${ }^{32-37}$ During the period 1971-1985 the case fatality rate for hepatitis was $3 \cdot 56 / 1000$ notifications. The percentage of males in notified hepatitis cases ranged from $53.3 \%$ in 1985 to $58.8 \%$ in 1974 , averaging $55.2 \%$ during this period, compared to the USA $(60.8 \%)^{38}$ and the United Kingdom $(67.6 \%$ to $74 \cdot 2 \%)^{39-40}$

Annual reported incidence rates per year ranged from $0.051 \%$ in 1953 to $0.139 \%$ in 1979 , averaging $0.087 \%$ during the period $1971-1985$. In different Israeli populations, Sandler ${ }^{35}$ and Green $^{30}$ reported attack rates $0 \cdot 119 \%$ and $0 \cdot 125 \%$. Eliakim ${ }^{32}$ reported that annual incidence rates based on Ministry of Health data varied between $0.051 \%$ and $0.132 \%$ for the period 1953-1974. These rates were then adjusted to between $0.18 \%$ and $0.297 \%$ when data based on ambulatory records at the insuring sick fund were used, reflecting a far higher reporting rate.

Published reports indicate that acute hepatitis B infection accounts for less than $9 \%$ of all hepatitis among Jews in Israel, with a further $11 \%$ having "non-A non-B" (mainly hepatitis $\mathrm{C}$ ) hepatitis infection. ${ }^{41}$ Around $10 \%$ of acute viral hepatitis in Israeli Defence Force conscripts is of type $\mathrm{B},{ }^{35} 15 \%$ in Ethiopian immigrants, ${ }^{42}$ and as high as $29.4 \%$ in pregnant women. ${ }^{43} \mathrm{Schwartz}^{28}$ estimated only $65 \%$ of cases to be type $\mathrm{A}$; however, higher estimates approaching $80 \%$ for hepatitis $\mathbf{A}$ infection were found in other Israel studies. ${ }^{343842}$ An estimate of $17.9 \%$ was used, based on the newly established system which began reporting hepatitis by type in January 1992; this is considerably lower than that reported in the USA $\left(30.9 \%\right.$ in 1987). ${ }^{44}$

\section{Hospital admissions}

The most recent available hospital admission data by diagnosis are those of 1979 when 1288 persons ( $55.4 \%$ male) or $24.4 \%$ of reported hepatitis cases were admitted with hepatitis as their primary diagnosis, with an average length of stay of 9.7 days ${ }^{46}$ compared with $9 \cdot 4$ days in $1976 .{ }^{47} \mathrm{~A}$ small meta-analysis, based on the combined information of various case studies between 1972 and 1982,314548 calculated the average length of stay for hepatitis $B$ cases to be 12.5 days, compared with 12 days in the USA ${ }^{49}$ and 12.8 days in England..$^{50}$ This was only $11.7 \%$ longer than that of non-type-B hepatitis stays (11.2 days). The percentage of all notifications admitted to hospital in Israel $(44.6 \%)$ during the period 1971$1980^{24} 25$ was similar to that found in west London $(48 \%))^{39}$ The percentage of all hospital admissions for type B hepatitis found in various Israeli case studies ranged between $12.2 \%$ and $28.9 \% .3545485152$ Case studies have found a predominance (ranging from $65 \%{ }^{45}$ to $75 \%{ }^{53} 54$ ) of males among persons admitted to hospital for hepatitis B.

\section{STRATEGIES AND ASSUMPTIONS}

There are four main vaccination strategies: (1) active vaccination of every newborn without prevaccination screening of mothers for hepatitis $B$ virus; (2) screening pregnant women followed by passive-active vaccination of babies at risk; (3) screening pregnant women followed by active vaccination of babies at risk; (4) screening pregnant women followed by active vaccination of babies at risk whose mothers are surface antigen positive $(\mathrm{HBsAg}+)$ and $\mathrm{e}$ antigen negative $(\mathrm{HBeAg}-)$ and with active and passive vaccination of at-risk babies whose mothers are $\mathrm{HBsAg}+/ \mathrm{HBeAg}+$.

\section{Strategy 1}

Instituting a policy of inoculating all newborns by active vaccination (strategy 1 ) would reduce horizontal and vertical transmissions. Such a programme should operate for 45 years from 1990 until 2034 to ensure the near elimination of vertical and horizontal transmission risk within families. This specific programme does not include the provision of any booster doses in future years.

Perinatal transmission from an infected mother to her newborn varies from $12.5 \%$ to $90 \%$ depending on the hepatitis $\mathrm{E}$ antigen $(\mathrm{HBeAg})$ status of the carrier mother. ${ }^{12} 20213255-60 \mathrm{~A}$ recent study among children born in the USA to Southeast Asian refugees found higher hepatitis B rates among children whose mothers were $\mathrm{HBsAg}$ carriers at birth and among children who lived in households with carrier siblings, suggesting both perinatal and horizontal child to child transmission paths. ${ }^{61}$ We assumed a sensitivity of $98 \%$ for the HBsAg test and a transmission rate of $16.5 \%$, being the midpoint of an $8-25 \%$ range relevant to Israel where approximately $98 \%$ of $\mathrm{HBsAg}$ carriers have antibodies to the $\mathrm{E}$ antigen (anti-HBe +) and less than $10 \%$ of $\mathrm{HBsAg}+/$ anti-HBe + mothers are also hepatitis $B$ virus-DNA +.6062

Projections of the numbers of newborns were based on the 100757 births in 1989, and a crude birth rate of $22 \cdot 1 / 1000$, adjusted downwards by a factor of $0 \cdot 1 / 1000$ per year, to reflect expected demographic changes in the population.

Earlier studies reported a range of vaccine efficiency rates from $70 \%$ to $96.8 \%$ for different protocols of hepatitis B immunoglobulin (HBIG) and active hepatitis $B$ virus inoculation. ${ }^{64-68} \mathrm{We}$ used a vaccine efficacy figure of $95 \%{ }^{69}$ for a three dose hepatitis B vaccine protocol. It is now believed that in areas where the majority of $\mathrm{HBsAg}+$ mothers are anti-HBe positive there is no need also to provide HBIG. ${ }^{70} 71$

Approximately $10 \%$ of vaccinees are expected to report temporary soreness or erythrema at the injection site. ${ }^{63372}$ In total, minor reactions are expected to occur in $25 \%$ of vaccinees. ${ }^{14}$ Approxi- 
mately $10 \%$ of these reactions will result in a physician visit ${ }^{73}$ costing $\$ 4.67$ each ( 15 minutes at $\$ 16$ per hour physician costs plus five minutes of secretarial or nurse costs at $\$ 8$ per hour). Shaw et $a l^{74}$ reported 41 neurological adverse events (including five convulsions, 10 Bell's palsy, and nine Guillain-Barré syndrome) in 850000 persons who received hepatitis $B$ vaccination $(0.0048 \%)$. Approximately $0.001 \%$ of children are expected to have severe adverse reactions, assumed to require three days of care in a general hospital ward at $\$ 265$ per day, and two days of intensive care at $\$ 794$ per day for an acute reversible condition ${ }^{75}$ costing $\$ 2383$ per case.

The figure of 3.08 severe reactions in 1990 probably represents an overestimate, since babies reacting severely to the first vaccination are unlikely to be revaccinated. There are no known serious chronic side effects of the vaccination in neonates. ${ }^{12646676}$ It was assumed that there would be no fatalities as a result of the vaccination campaign due to improvements in the vaccine incorporated since Mulley's study, ${ }^{14}$ which assumed a fatality rate of one per million vaccinations.

Based on a cost of $\$ 2.30$ per paediatric dose, ${ }^{77}$ with a vaccine wastage rate of $6 \%$, the cost of three doses (including syringes and swabs) for the estimated 102514 newborns in 1990 is $\$ 799415$ (including $\$ 43210$ for adverse reactions). The net present value of costs to the health services (using a $7.5 \%$ discount rate) of a programme from 1990 to 2034 is $\$ 13.81$ million (including $\$ 0.75$ million for adverse reactions).

\section{Strategy 2}

An alternative strategy (number 2) would be to screen each mother for $\mathrm{HBsAg}$ at a cost of approximately $\$ 7 \cdot 17$ per test. Only children born to positive mothers would then be given an HBIG dose (costing \$20) and three hepatitis $B$ vaccine doses. Our calculation of the number of children born to positive mothers included adjustments for multiple births and stillbirths. ${ }^{78}$ Total health service costs for 1990 are $\$ 741165$ including $\$ 705602$ for screening mothers, $\$ 25970$ for providing HBIG to neonates, $\$ 9704$ for hepatitis B vaccinations, and $\$ 519$ for adverse reactions.

\section{Strategy 3}

A protocol of screening mothers and using only three active hepatitis B vaccinations to neonates at risk (strategy 3) will cost $\$ 715195$ in 1990, representing a saving of $\$ 25970$ in HBIG costs over strategy 2 . Since the total cost of strategies 2 or 3 using screening is virtually the same as that

Table I Costs of screening strategies ( $S$ millions) (including adverse reactions)

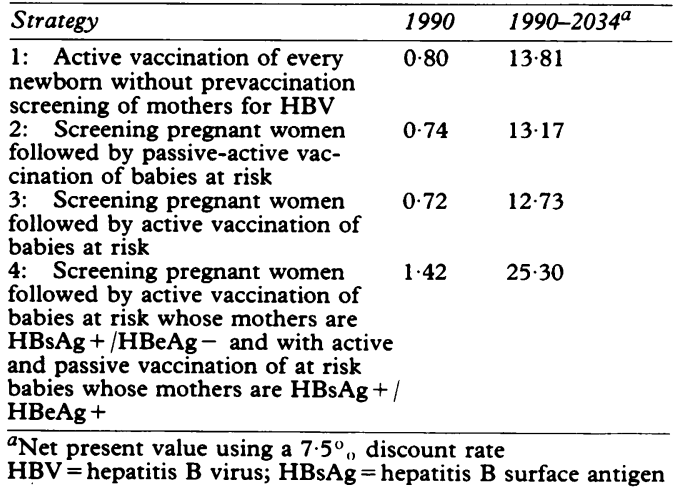

for inoculating all neonates, substantial savings will only occur if the percentage of $\mathrm{HBsAg}$ positive mothers is considerably lower than the $2.0 \%$ figure used in this paper, or the price of three child doses of hepatitis $B$ vaccine rises relative to $\mathrm{HBsAg}$ test costs.

\section{Strategy 4}

Strategy 4 would involve screening not only for HBsAg but also for anti-HBe status. This would enable active hepatitis $B$ vaccinations to be given to at-risk babies whose mothers are anti-HBe positive, and active-passive vaccinations to be given to the $2 \%$ of at-risk babies whose mothers are $\mathrm{HBeAg}$ positive. On account of the extra costs of the HBeAg screening tests the total cost of strategy 4 in 1990 will be around $\$ 1.42$ million, making it the least cost-effective of all the screening options.

\section{COSTS AND CHOICE OF STRATEGIES}

Table I lists the costs in 1990 and the discounted costs for the period 1990-2034 of carrying out the four vaccination strategies. Screening strategy 4 is rejected as it is by far the most expensive. Strategies 2 and 3 are rejected in favour of strategy 1 , which provides protection for all newborns, as there are not only economic cost-effectiveness considerations but also ethical considerations in favour of providing protection for the large number of babies whose mothers do not fall into the at-risk category. For example, vaccinating the entire newborn population would only increase costs by around 3.4 to $8.5^{\circ}{ }_{0}$; in contrast, if we choose to prescreen mothers and vaccinate only babies at risk (strategies 2 or 3 ), only $2 \cdot 0-2 \cdot 5^{\circ}{ }_{0}$ of newborns will be covered instead of $100^{\circ}{ }_{0}$ (assuming full compliance). A disadvantage of both strategies 2 and 3 is that they provide no protection for the $98.0^{\circ}$ o of children born to hepatitis $\mathrm{B}$ surface antigen negative $(\mathrm{HBsAg}-$ ) mothers and only represent small savings over the use of strategy 1 . These children will be at risk for infection through horizontal transmission, for example from an $\mathrm{HBsAg}+$ father or sibling. As a result the effectiveness of these strategies is likely to be lower than that of inoculating all neonates. Therefore the vaccination of all neonates (strategy 1) is likely to be more cost-beneficial than a strategy of universal screening with a passiveactive or active immunisation. The remainder of this paper will consist of a cost-benefit analysis of strategy 1 , the active vaccination of every newborn without prevaccination screening of mothers for hepatitis B virus.

The cost-benefit analysis is based on a vast array of demographic data (age structures and projections, labour force participation), epidemiological data (hepatitis incidence and transitory probabilities to hepatocellular carcinoma), health service data (type and amount of care required for hepatitis cases), and economic data (costs of inoculation, costs of caring for hepatitis cases). These were entered into a model using a Lotus 1-2-3 spreadsheet. The major advantage of having the model on a spreadsheet (in comparison to writing the model in program form) was the relative ease of adding in new values as new information became available, changing the model specification and performing sensitivity analyses. 
Results

COST OF TREATING HEPATITIS B CASES

Vaccination using strategy 1 will result in a considerable reduction in hepatitis $\mathrm{B}$ morbidity and mortality. The appendix lists the costs of visits, hospital admissions and laboratory tests, as obtained from the Ministry of Health and the General Sick Fund (which insures over $75 \%$ of the population).

The prices of many tests and assays exceed those reported in earlier papers based on European $^{5079}$ and American data. ${ }^{12} 14$ The higher Israeli costs could be due to a combination of higher imported equipment costs, discriminatory market differential pricing by drug suppliers, inefficient laboratory practices, and high price to real cost differentials in the price lists of the Ministry of Health and Sick Funds. Since outlays for medication and surgery are usually minimal in hepatitis B patients and outweigh any increased isolation costs, the hospital costs for hepatitis B are assumed to be only $85 \%$ of the average $\$ 265$ per diem hospital admission fee.

The appendix also lists estimates based on current practice in Israel of the quantity of services applicable to various forms of hepatitis B. Table II shows the cost by type and stage of hepatitis $B$ as well as the transitional probabilities of developing further stages of hepatitis B by vaccination status. ${ }^{14}$ An annual discount rate of $7.5 \%$ was used over a 20 year time horizon in order to aggregate expenditures incurred by chronic, persistent, and carrier cases across time. Based on experience in Israel, only $1 \%$ of carriers were assumed to present themselves for examination. Chronic active hepatitis B encompasses

Table II Direct costs of hepatitis B by stage

\begin{tabular}{|c|c|c|c|}
\hline & \multicolumn{2}{|c|}{ Outcome $\left({ }^{\circ}{ }_{0}\right.$ of cases $)$} & \multirow{2}{*}{$\begin{array}{l}\text { Direct } \\
\text { costs }\end{array}$} \\
\hline & Unvaccinated & Vaccinated & \\
\hline $\begin{array}{l}\text { Subclinical } \\
\text { Anicteric } \\
\text { Icteric }\end{array}$ & $\begin{array}{l}50 \cdot 00 \\
30 \cdot 00 \\
19 \cdot 90\end{array}$ & $\begin{array}{l}75.00 \\
13.00 \\
11.99\end{array}$ & $\begin{array}{r}\$ 0 \\
\$ 477 \\
\$ 888\end{array}$ \\
\hline $\begin{array}{l}\text { Non-fulminant } \\
\text { Resolved } \\
\text { Asymptomatic carrier } \\
\text { Persistent } \\
\text { Chronic active }\end{array}$ & $\begin{array}{l}99.90 \\
89.91 \\
4.995 \\
3.497 \\
1.499\end{array}$ & $\begin{array}{l}99 \cdot 00 \\
98 \cdot 01 \\
0.495 \\
0.347 \\
0 \cdot 149\end{array}$ & $\begin{array}{r}\$ 0 \\
\$ 59 \\
\$ 2111 \\
\$ 20176\end{array}$ \\
\hline $\begin{array}{l}\text { Fulminant } \\
\text { Resolved } \\
\text { Asymptomatic carrier } \\
\text { Persistent } \\
\text { Active } \\
\text { Fatal }^{a}\end{array}$ & $\begin{array}{l}0 \cdot 10 \\
0 \cdot 0200 \\
0 \cdot 0050 \\
0 \cdot 0035 \\
0 \cdot 0015 \\
0 \cdot 0700\end{array}$ & $\begin{array}{l}0.01 \\
0.0020 \\
0.0005 \\
0.0004 \\
0.0002 \\
0.0070\end{array}$ & $\begin{array}{r}\$ 3672 \\
\$ 59 \\
\$ 2111 \\
\$ 20176 \\
\$ 8341 \\
\end{array}$ \\
\hline
\end{tabular}

${ }^{a}$ In addition there are mortality costs of $\$ 40304$

Table III Benefit and cost of hepatitis B neonatal vaccinations (\$US millions)

\begin{tabular}{|c|c|c|c|}
\hline & Direct & $\begin{array}{l}\text { Direct } \\
\text { and work }\end{array}$ & $\begin{array}{l}\text { Direct and } \\
\text { mortality } \\
\text { and work }\end{array}$ \\
\hline $\begin{array}{l}\text { Newborn shots + boosters } \\
\text { Adverse reactions } \\
\text { Total costs }\end{array}$ & $\begin{array}{c}13 \cdot 06 \\
0 \cdot 75 \\
13 \cdot 8\end{array}$ & $\begin{array}{c}13 \cdot 06 \\
0 \cdot 75 \\
13 \cdot 8\end{array}$ & $\begin{array}{c}13.06 \\
0.75 \\
13.8\end{array}$ \\
\hline $\begin{array}{l}\text { Hepatitis costs without vaccination } \\
\text { Hepatitis costs with vaccination } \\
\text { Benefits } \\
\text { Benefit to cost ratio }\end{array}$ & $\begin{array}{r}23 \cdot 5 \\
2 \cdot 7 \\
20 \cdot 9 \\
1 \cdot 51\end{array}$ & $\begin{array}{c}60 \cdot 77 \\
23 \cdot 33 \\
37 \cdot 4 \\
2 \cdot 71\end{array}$ & $\begin{array}{l}61 \cdot 7 \\
23 \cdot 7 \\
38 \cdot 0 \\
2 \cdot 75\end{array}$ \\
\hline $\begin{array}{l}\text { HCC costs without vaccination } \\
\text { HCC costs without vaccination } \\
\text { Benefits } \\
\text { Total benefits }\end{array}$ & $\begin{array}{l}1 \cdot 36 \\
0.73 \\
0.63 \\
21 \cdot 5\end{array}$ & $\begin{array}{l}1 \cdot 43 \\
0 \cdot 77 \\
0 \cdot 66 \\
38 \cdot 1\end{array}$ & $\begin{array}{c}1 \cdot 49 \\
0 \cdot 80 \\
0 \cdot 69 \\
38 \cdot 7\end{array}$ \\
\hline Benefit to cost ratio (incl HCC) & 1.56 & $2 \cdot 76$ & $2 \cdot 80$ \\
\hline
\end{tabular}

$\mathrm{HCC}=$ hepatocellular carcinoma
$30-60 \%$ of cirrhosis cases during the first 20 years following acute infection. ${ }^{80-82}$

Rapid death from fulminant hepatitis (median age of 45 years $^{14}$ ) incurs $\$ 8341$ in health care costs during only seven days in an intensive care unit. Such intensive care was assumed to cost $\$ 1192$ per day, 4.5 times the average per day hospital cost on account of such factors as intensive care and blood products.

The cost of each stage of hepatitis B was multiplied by its probability of occurrence in order to calculate the average cost of hepatitis B per case. Because of the assumed greater severity of hepatitis in an unvaccinated patient, ${ }^{14}$ the average direct cost was nearly 3.5 times that of a non-responder vaccinee ( $\$ 706 v \$ 207)$.

\section{BENEFITS}

The proposed nationwide intervention programme is based on a three dose vaccine to all neonates from 1990 to 2034 . The triple dose is expected to provide protection for at least five years. Estimates of vaccination efficiency have ranged between $70 \%$ and $95 \% .46131741435461$ 64 83-86 We used the upper estimate of $95 \%$ reflecting improved developments in vaccination techniques. We assumed that the incidence rate of hepatitis $B$ in vaccinees and the transmission rate from mothers to neonates would fall by the vaccine's efficacy rate of $95 \%$ during the first five years of life. As no data are available on the effectiveness of the vaccine for longer periods, we assumed that vaccine efficiency would fall by $15 \%$ every five years thereafter, being $80.75 \%$ $(95 \% \times 85 \%)$ after 10 years, $68.64 \%$ $(95 \% \times 85 \% \times 85 \%)$ after 15 years, etc. Assuming full compliance, this will reduce the number of cases in the cohort of persons who received a vaccination as neonates from 203 to 10 in 1990 and from 25867 to 13772 in 2035. An alternative option is to revaccinate every five years with a single booster injection until the age of 40 years. This would add an additional cost of around $\$ 11$ million to the project during the period 19902035.

In addition to an absolute decrease in the number of cases, the case mix of hepatitis $B$ and its complications will become less severe as a result of vaccination $^{14}$ (see table II).

The main monetary benefits of vaccination are the costs averted in caring for a reduced number of cases of hepatitis B. Reductions in incidence rate were multiplied by population estimates (assuming a $2 \%$ annual geometric growth rate in addition to an estimated immigration of 900000 from the former USSR and 25000 from Ethiopia during the 1990s) multiplied by the relevant unit cost per case depending on vaccination status (table II).

Benefits also occurred due to the reduction in numbers of neonates expected to develop hepatocellular carcinoma, since in the absence of a neonatal vaccination programme, $2.5 \%$ of neonates who acquire hepatitis $B$ from their mothers are expected to develop hepatocellular carcinoma, and are expected to die from this condition ${ }^{67}$ at a mean age of either 45 or 64 years, depending on whether their mothers were $\mathrm{HBe}+$ or $\mathrm{HBe}-$ respectively. ${ }^{69}$ Calculations earlier in this paper found chronic hepatitis costs to be $11.1 \%$ higher than those reported by Arevalo. This differential 
percentage was applied to Arevelo's hepatocellular carcinoma costing ${ }^{12}$ resulting in an Israel care cost estimate of $\$ 41048$ per case (at 1990 price levels) for hepatocellular carcinoma in the 44 th or 64 th year of life.

COST-BENEFIT ANALYSES (table III)

Implementation of the neonatal vaccination policy would reduce the number of hepatitis $B$ cases in the cohort from 359343 to 166224 during the period 1990-2035, and generate direct health service benefits of $\$ 21.5$ million, which exceeds the direct programme costs of $\$ 13.8$ million, yielding a benefit to cost ratio of $1 \cdot 56 / 1$.

\section{Discussion}

The present study was designed to estimate the costs and benefits of a hepatitis $B$ prevention programme to neonates in an area of intermediate endemicity, where the majority of $\mathrm{HBsAg}$ carriers are anti-HBe positive.

Israel is located in the Middle East, a region considered to be one where there are intermediate risks of developing hepatitis B during a lifetime, compared to the high risk regions of the Far East and Africa or the low risk regions of Western Europe and the USA.

Israel's estimated carrier population of $2 \cdot 0-2 \cdot 5^{\circ}{ }_{0}$ (depending on the mix of ethnic backgrounds) means that every year about 2500 babies will be at risk of acquiring hepatitis $B$ infection, due to vertical and horizontal transmission. In addition, according to current estimates there are at present $60000-80000 \mathrm{HBsAg}$ carriers in the general population who may transmit the disease horizontally. Since $98^{\circ}{ }_{0}$ of Israeli carriers are anti-HBe positive (of whom $6-8^{\circ}{ }_{0}$ still have circulating hepatitis $\mathrm{B}$ virus $\mathrm{DNA}^{86}$ ) the magnitude of the problem is less than that in Asia or Africa, but is still larger than that in Western Europe or the USA.

By instituting a national neonatal vaccination policy, the net savings in direct health service costs (ie, benefits less vaccination costs) in the 1990-2034 period would be $\$ 7.8$ million $(\$ 7 \cdot 2$ million if hepatocellular carcinoma costs are excluded). The cost calculations assumed that no extra transportation costs of parents, labour costs, administration costs, or work losses would occur, as the three doses could be integrated within existing infant inoculation schedules agains polio. In any case, most previously employed mothers would still be on maternity leave (three months paid and up to one year unpaid).

Table IV Benefit-cost ratios by reporting, discount rate, adult vaccine cost: neonatal programme

\begin{tabular}{|c|c|c|c|c|c|c|}
\hline \multirow{2}{*}{$\begin{array}{l}\text { Discount } \\
\text { rate }\end{array}$} & \multicolumn{3}{|c|}{$\begin{array}{l}\text { Direct costs and benefits } \\
\text { (vaccine decay rate) }\end{array}$} & \multicolumn{3}{|c|}{$\begin{array}{l}\text { Total cost and benefits } \\
\text { (vaccine decay rate) }\end{array}$} \\
\hline & $0 \%$ & $15 \%$ & $30^{\circ} \%$ & $0_{0}^{\circ}$ & $15^{\circ}$ & $30^{\prime \prime}{ }_{1 \prime}$ \\
\hline $\begin{array}{c}10 \% \\
7.5 \% \\
5.0 \% \\
0 \%\end{array}$ & $\begin{array}{r}1 \cdot 11 \\
1 \cdot 78 \\
3 \cdot 21 \\
21 \cdot 31\end{array}$ & $\begin{array}{r}0.99 \\
1.56 \\
2.69 \\
14.50\end{array}$ & $\begin{array}{l}\text { Repo } \\
0.92 \\
1.45 \\
2.42 \\
10.86\end{array}$ & $\begin{array}{r}\text { ate } 33 \cdot 3 \\
2 \cdot 78 \\
3 \cdot 36 \\
5 \cdot 66 \\
27 \cdot 01\end{array}$ & $\begin{array}{r}1 \cdot 79 \\
2.80 \\
4.61 \\
19.07\end{array}$ & $\begin{array}{r}1.30 \\
2.10 \\
3.43 \\
14.99\end{array}$ \\
\hline $\begin{array}{l}10 \% \\
7 \cdot 5 \% \\
5 \cdot 0 \% \\
0 \%\end{array}$ & $\begin{array}{r}0 \cdot 76 \\
1 \cdot 20 \\
2 \cdot 16 \\
14 \cdot 29\end{array}$ & $\begin{array}{l}0.68 \\
1.06 \\
1.82 \\
9.75\end{array}$ & $\begin{array}{l}\text { Repo } \\
0.64 \\
0.98 \\
1.64 \\
7.34\end{array}$ & $\begin{array}{c}\text { ate } 50 \cdot 0 \\
1.45 \\
2 \cdot 27 \\
3.81 \\
18 \cdot 11\end{array}$ & $\begin{array}{r}1 \cdot 23 \\
1 \cdot 90 \\
3 \cdot 11 \\
12 \cdot 81\end{array}$ & $\begin{array}{r}0.95 \\
1.44 \\
2.32 \\
10 \cdot 13\end{array}$ \\
\hline
\end{tabular}

Averted mortality, or savings of life years, is an indirect benefit of the vaccination programme. Using the human capital method of valuing life, with the deceased's future lost earnings discounted at $7 \cdot 5^{\circ}$ o per annum, mortality costs of $\$ 40304$ were estimated for mortality from hepatocellular carcinoma or fulminant hepatitis in those who died aged 45 years. This method only gives a valuation of $\$ 9677$ to those who died from hepatocellular carcinoma at the age of 64 .

A further indirect benefit is that resulting from a reduction in work losses as a result of decreased morbidity. Such work losses were calculated by multiplying the age and sex specific labour force participation rates by age and sex specific wage costs, ${ }^{79}$ and the age specific notification rates ${ }^{24-26}$ of hepatitis B cases. Data were adjusted by an estimated unemployment rate of $10^{\circ} 0^{\circ}{ }_{0}$ in 1991 .

As no Israeli data were available on work absences due to hepatitis virus infections (in cohort members who have reached working age) regardless of aetiology, we used Adler's estimate from England ${ }^{50}$ of 117.3 days per year, adjusted upward for the five and a half day Israeli work week, to 123.2 days per year. This estimate was applied to each stage of hepatitis B, except subclinical and fatal fulminant forms. The fatal fulminant form was estimated to cause 20 lost work days before death. An additional calculation was made of work losses incurred by working parents (assumed to be females aged between 18 and 34 years), who were estimated to be at home to care for their unwell children for 30 days, reflecting the shorter duration of the illness in children.

When indirect benefits from decreased work absences are included, the benefit ( $\$ 38.1$ million) to cost ratio rises to $2 \cdot 76 / 1$. Addition of averted mortality costs increases benefits to $\$ 38.7$ million, and the benefit to cost ratio to $2 \cdot 80 / 1$ (table III), a saving to the country of around $\$ 25.4$ million ( $\$ 24.7$ million excluding hepatocellular carcinoma costs)

Unfortunately data in Israel are unavailable for age specific hepatocellular carcinoma cases regarding the age at onset of the initial hepatitis $B$ infection. If the average age of hepatocellular carcinoma has been overstated in the neonatal group (ie, it is considerably less than 64 years), then the benefit to cost ratios will be biased downwards.

A sensitivity analysis was performed using different discount, vaccine effectiveness decay, and reporting rates (table IV). This analysis found the benefit to cost ratio to be particularly sensitive to the choice of discount rate, the direct benefit to cost ratio rising to $2 \cdot 69 / 1$ using a $5^{\circ}$ " rate and to $14.50 / 1$ using a zero discount rate. A zero discount rate was included to take into account the argument that using a positive discount rate in a health study with a long time horizon effectively gives very little value to net decreases in morbidity or mortality enjoyed in the distant future, harming intergenerational equity. This zero discount rate gives equal weight to any decreases in mortality and morbidity, even in the distant future.

It could be argued that, since the memory of the immune system has been programmed, if there is any further encounter with viruses there will be an anamnestic reaction, thus effectively reducing the 
vaccine effectiveness decay rate to $0 \%$ (ie, remaining at $95 \%$ effective throughout the person's lifetime). The sensitivity analysis showed that with a $0 \%$ vaccine decay rate, the direct benefit to cost ratio increases to $1 \cdot 78 / 1$, with the total benefit to cost ratio rising to $3 \cdot 36 / 1$. If the reporting rate rose to $50 \%$, the direct benefit to cost ratio (using a $7.5 \%$ discount rate and $85 \%$ vaccine efficiency rate) decreases to $1 \cdot 06 / 1$, the total benefit to cost ratio being $1 \cdot 90 / 1$.

In keeping with the conservative nature of our estimates, the cost of transport and time involved in visiting a child in hospital was omitted in the valuation of benefits. It was also assumed that parents will accompany children on ambulatory visits outside of their working hours. No valuation was given to the benefit of having an increased potential pool of blood donors in the population, since around $1.5 \%$ of all blood donations in Israel are disqualified on account of $\mathrm{HBsAg}$ positivity $(\mathrm{S}$ Bar-Shani, personal communication).

The benefit to cost ratios are biased downward by the fact that we have conservatively assumed there to be no reduction in the incidence of persons who had never been vaccinated. As a result of herd immunity, these people will also have a reduction in hepatitis $\mathbf{B}$ incidence, an external benefit of the vaccination programme. The omitted major costs of liver transplant operations, each costing around $\$ 44000$ if performed in Israel (and around $\$ 88000$ if performed in Europe), plus an additional $\$ 44000$ to cover antiviral drugs currently used on an experimental basis to prevent reinfections, would also contribute to a downward bias. No valuation was put on the intangible benefit of freedom from anxiety concerning contracting hepatitis $\mathrm{B}$ that members of Israeli society might experience. Finally, no attempt was made to monetarise the benefits in such important but intangible dimensions as reduced pain, worry, or grief as morbidity and mortality decrease.

The incidence estimates which underpinned the cost-benefit analysis took into account the fact that between $25 \%$ and $40 \%$ of the Soviet Jewish immigrants have been infected with hepatitis B prior to their arrival in Israel (D Shouval, personal communication). Consideration could also be given to inoculating all new immigrants from the USSR under a certain age against hepatitis B, like the high risk group strategy currently being implemented for recent immigrants from Ethiopia under the age of two years. ${ }^{87}$

Implementation of a neonatal vaccination programme would result in a decrease in almost 200000 hepatitis B cases over the 1990-2035 period. This huge decrease in morbidity can be gained at no net cost to society; indeed a net savings of around $\$ 25.4$ million would accrue to society. Approximately $\$ 7 \cdot 7$ million of this will be savings to the health services, sufficient to finance around 90 liver transplants or around 900 coronary bypass operations. The adoption of a nationwide policy of inoculating neonates appears to be not only medically but also economically justifiable.

Appendix

Costs of visits, hospital admissions, and laboratory tests for hepatitis B cases

\begin{tabular}{|c|c|c|c|c|c|c|c|c|c|c|c|c|c|c|}
\hline \multirow[b]{2}{*}{$\%$ Receiving care } & \multirow[b]{2}{*}{$\begin{array}{l}\text { Anicteric } \\
100 \%\end{array}$} & \multicolumn{2}{|l|}{ Icteric } & \multicolumn{2}{|c|}{ Fulminant } & \multicolumn{2}{|c|}{ Carrier } & \multicolumn{2}{|c|}{ Persistent } & \multicolumn{5}{|c|}{ Chronic active } \\
\hline & & $\begin{array}{l}\text { Hosp } \\
100 \%\end{array}$ & $\begin{array}{l}\text { Non- } \\
\text { hosp } \\
100 \% \\
\end{array}$ & $\begin{array}{l}\text { Fatal } \\
100 \%\end{array}$ & $\begin{array}{l}\text { Non- } \\
\text { fatal } \\
100 \% \\
\end{array}$ & $\begin{array}{l}\mathrm{Yr}_{1} 1 \\
1 \%\end{array}$ & $\begin{array}{l}\text { Yrs } \\
2-20 \\
1 \% \\
\end{array}$ & $\begin{array}{l}\text { Yr } 1 \\
100 \%\end{array}$ & $\begin{array}{l}\text { Yrs } \\
2-20 \\
100 \% \\
\end{array}$ & $\begin{array}{l}\text { Yr } 1 \\
100 \%\end{array}$ & $\begin{array}{l}\text { Yrs 2-5 } \\
20 \%\end{array}$ & $\begin{array}{l}\text { Yrs 2-5 } \\
80 \%\end{array}$ & $\begin{array}{l}\text { Yrs } \\
6-10 \\
100 \% \\
\end{array}$ & $\begin{array}{l}\text { Yrs } \\
11-20 \\
100^{\circ} \\
\end{array}$ \\
\hline $\begin{array}{l}\text { Physician visit } \\
\text { (\$4.67 per } 15 \mathrm{~min} \text { ) } \\
\text { Medication }\end{array}$ & 1 & 1 & 1 & & 1 & 7 & 1 & 4 & 4 & 1 & 10 & 3 & 3 & 3 \\
\hline $\begin{array}{c}(\$ 1825 \text { per year }) \\
\text { Hep A tests }(\$ 14 \cdot 34)\end{array}$ & 1 & 1 & 1 & & 1 & 1 & & 1 & & 1 & 1 & 1 & & \\
\hline $\mathrm{HBsAg}$ test $(\$ 7.17)$ & 1 & 1 & 1 & & 1 & 1 & 1 & 1 & 1 & $i$ & & & & \\
\hline $\begin{array}{l}\text { Anti-HB assay } \\
(\$ 7.17)\end{array}$ & 1 & 1 & 1 & & 1 & 1 & & 1 & & 1 & & & & \\
\hline $\begin{array}{l}\text { Tests: urine }+ \\
\text { bilirubin }(\$ 11.55)\end{array}$ & 1 & 1 & 1 & & 1 & 1 & & 1 & & 1 & & & & \\
\hline $\begin{array}{l}\text { blood count } \\
\text { (\$12.65) }\end{array}$ & 1 & 1 & 1 & & 1 & 1 & & 1 & & 1 & & & 3 & 3 \\
\hline $\begin{array}{l}\text { iver trunction uncl } \\
\text { bilirubin (\$19) }\end{array}$ & 1 & 0 & 1 & & 1 & 1 & 1 & 4 & 4 & 1 & & & 3 & 3 \\
\hline$(\$ 17.60)$ & 1 & 3 & 1 & & 1 & 1 & 1 & 1 & & 1 & & & 3 & 3 \\
\hline (\$109.50) & & & & & & & $1($ aged $40+)$ & 1 & 1 & 1 & 1 & 1 & 1 & 1 \\
\hline $\begin{array}{l}\text { endoscopy } \\
(\$ 217.00)\end{array}$ & & & & & & & & & & 1 & 1 & 1 & 1 & 1 \\
\hline $\begin{array}{l}\alpha \text { fetoprotein } \\
(\$ 14.50)\end{array}$ & & & & & & & $1($ aged $40+)$ & 1 & 1 & 1 & 1 & 1 & 1 & 1 \\
\hline $\begin{array}{l}\text { Convalescent visits } \\
\text { (\$4.67) } \\
\text { (\$b follow up: }\end{array}$ & 2 & 6 & 6 & & 6 & & & & & 2 & & & & \\
\hline $\begin{array}{l}\text { Lab follow up: } \\
\text { blood count } \\
\text { liver function incl }\end{array}$ & 1 & 1 & 1 & & 1 & & & & & 1 & 3 & 3 & & \\
\hline $\begin{array}{l}\text { hver function incl } \\
\text { bilirubin } \\
\text { PT /PTT tests }\end{array}$ & 3 & 3 & 3 & & 3 & & & & & 3 & 3 & 3 & & \\
\hline $\begin{array}{l}\text { PT/PTT tests } \\
\text { Post-convalescent }\end{array}$ & 1 & 1 & 1 & & 1 & & & & & 1 & & 3 & & \\
\hline $\begin{array}{l}\text { visit }(\$ 4 \cdot 67) \\
\text { HBsAg test } \\
\text { ANTI-HB assay }\end{array}$ & $\begin{array}{l}1 \\
1 \\
1\end{array}$ & $\begin{array}{l}1 \\
1 \\
1\end{array}$ & $\begin{array}{l}1 \\
1 \\
1\end{array}$ & & $\begin{array}{l}1 \\
1 \\
1\end{array}$ & & & & & $\begin{array}{l}1 \\
1 \\
1\end{array}$ & 1 & 1 & 1 & 1 \\
\hline $\begin{array}{l}\text { Liver biopsy (\$265 } \\
\text { a day: } 2 \text { days) } \\
\text { Hospital admission }\end{array}$ & & & & & & & & $100 \%$ & & $100 \%$ & $100 \%$ & $0 \%$ & $20 \%$ & $40 \%$ \\
\hline $\begin{array}{l}\text { (\$225 a day: } \\
5 \text { days) }\end{array}$ & $10 \%$ & $25 \%$ & & $70 \%$ & $30 \%$ & & & $100 \%$ & & $100 \%$ & $100 \%$ & & & \\
\hline $\begin{array}{l}\text { Hepatitis LOS } \\
\text { (\$225 a day) }\end{array}$ & $10 \cdot 6$ & $10 \cdot 6$ & & & 15 & & & & & & & & 5 & 5 \\
\hline $\begin{array}{l}\text { Biopsy LOS } \\
\text { (\$265 a day) } \\
\text { Fulminant LOS } \\
\text { (\$1192 a day) }\end{array}$ & & & & & & 1 & 1 & 2 & 2 & 2 & 2 & & & \\
\hline (\$1192 a day) & & & & 7 & & & & & & & & & & \\
\hline
\end{tabular}




\section{Postscript}

In May 1991, partly on the basis of information presented in earlier drafts of this paper, the infectious disease committee of the Ministry of Health unanimously proposed the adoption of neonatal vaccinations without screening (strategy 1). The vaccination of all newborns nationwide began in Israel in January 1992.

We wish to thank Professor J Aravelo of the University of California at Davis, Sacramento for his information regarding costings and Professor D Berns of the Israeli Chief Scientist's Office for his comments on this work. The opinions expressed in this article are those of the authors, and not necessarily of the Ministry of Health. This work was supported in part by the $S \mathrm{~K}$ Foundation (The Netherlands).

1 Soberlavsky O. HBV as a global problem. In: Vyas GN, Cohen SN, Schmid R, eds. Viral hepatitis. Philadelphia: Franklin Institute Press, 1978: 347-55.

2 Hoofnagle JH, Alter $\mathrm{H}$. Chronic viral hepatitis. In: Vyas $\mathrm{GN}$, Dienstag JL, Hoofnagle JH, eds. Viral hepatitis and liver disease. New York: Grune and Stratton, 1984: 97-113.

3 World Health Organization. Hepatitis B vaccines prepared from yeast by recombinant DNA techniques: memorfrom yeast by recombinant DNA techniques: memorandom from a WHO meeting. Bull WHO 1985; 63: 57-61.
Szmuness W, Harley EJ, Ikram H, Stevens CE Sociodemographic aspects of the epidemiology of hepatitis B. In: Vyas GN, Cohen SN, Schmid R, eds. Viral hepatitis. Philadelphia: Franklin Institute Press, 1978: 297-320.

5 Francis DP, Favero MS, Maynard JE. Transmission of hepatitis B virus. Semin Liver Dis 1981; 1: 27-32.

6 Szmuness W, Stevens CE, Harley EJ et al. Hepatitis B vaccine; demonstration of efficacy in a controlled clinical trial in a high risk population in the United States. $N$ Englf Med 1980; 303: 833-41.

7 Francis DP, Handler SC, Thompson SE, et al. Prevention of hepatitis B with vaccine: report from the Centers for Disease Control multi-center efficacy trial among homosexual men. Ann Intern Med 1982; 97: 362-6.

8 Maupas P, Chiron JP, Barin B, et al. Efficacy of hepatitis B vaccine in prevention of early $\mathrm{HBsAg}$ carrier state in
children: controlled trial in an endemic area (Senegal). children: controlled tria

$9 \mathrm{Xu} \mathrm{ZY}$, Liu CB, Francis DP, et al. Prevention of perinata acquisition of hepatitis $B$ virus carriage using vaccine: preliminary report of randomized, double-blind placebocontrolled and comparative trial. Pediatrics 1985; 76 713-8.

10 Wainwright RB, McMahon BJ, Bulkow LR, et al. Duration of immunogenicity and efficacy of hepatitis $B$ vaccine in Yupik Eskimo population. $₹ A M A$ 1989; 261: 2362-6.

11 McMahon BJ, Rhodes ER, Heyward WL. A comprehensive programme to reduce the incidence of hepatitis B viral infection and its sequelae in Alaskan natives. Lancet 1987; ii: $1134-6$.

12 Arevalo JA, Washington E. Cost-effectivness of prenata screening and immunization for hepatitis $\mathrm{B}$ virus. $\mathfrak{f} A M A$ screening and immur

13 Beasley RP, Hwang LY, Lee GC, et al. Prevention of perinatally transmitted hepatitis $B$ virus infections with hepatitis B immune globulin and hepatitis B vaccine. Lance 1983; ii; 1099-102

14 Mulley AG, Silverstein MD, Dienstag JL. Indications for use of hepatitis $B$ vaccine, based on cost-effectivnes analysis. $N$ Engl f Med 1982; 307: 644-52.

15 WHO Update. Expanded programme on immunization. Hepatitis B vaccine-attacking a pandemic. Geneva: WHO, 1989.

16 Gamen D. Persistent infection of humans with hepatitis $B$ virus: mechanism and consequences. Rev Infect Dis 1982; 1026-47.

17 Szmuzness W. Hepatocellular carcinoma and the hepatitis B virus: evidence for a causal association. Prog Med Virol 1978; 24: 40-62.

18 Maupas P, Melnick JL. Hepatitis B infection and primary liver cancer. Prog Med Virol 1981; 27: 1-15.

19 Beasley RP. Hepatitis B virus as the etiologic agent in hepatocellular carcinoma: epidemiologic considerations. Hepatology 1982; 2: 21-6S.

20 Prince AM, Alcabes P. The risk of development of hepatocellular carcinoma in hepatitis B virus carriers in New York. A preliminary estimate using death-records matching. Hepatology 1982; 2: 15-20S.

21 London WT. Primary hepatocellular carcinoma: etiology, pathogenesis and prevention. Hum Pathol 1981; 12: 108597.

22 Nayak NC, Dhar A, Sachdeva R, et al. Association of human hepatocellular carcinoma and cirrhosis with hepatitis B virus surface and core antigens in the liver. Int $\mathcal{f}$ Cancer 1977; 20: 643-54.

23 Beasley RP, Hwang LY, Lin CC, et al. Hepatocellular carcinoma with HBV: a prospective study of 22707 men in Taiwan. Lancet 1981; ii: 1129-33.
24 Central Bureau of Statistics. Statistical tables on selected infectious diseases 1971-1975. Special Series No 379. Jerusalem: Central Bureau of Statistics, 1977.

25 Central Bureau of Statistics. Statistical tables on selected infectious diseases 1976-1980. Special Series No 722 Jerusalem: Central Bureau of Statistics, 1983.

26 Central Bureau of Statistics. Statistical tables on selected infectious diseases 1981-1985. Special Series No 826. Jerusalem: Central Bureau of Statistics, 1988.

27 Reisler DM, Brachott D, Mosley JW. Viral hepatitis in Isreal: morbidity and mortality data. Am f Epidemiol 1970 92: 62-72.

28 Schwartz TA, Levin J, Ben Porat E. Epidemiology of hepatitis A in Israel. Monogr Virol 1984; 15: 53-8.

29 Kark JD, Bar Shani S. Hepatitis A antibody in Israel Defence Force recruits. F Med Virol 1981; 6: 341-5.

30 Green M, Block C, Slater P. Rise in the incidence of viral hepatitis in Israel in the face of improved socioeconomic conditions. Rev Infect Dis 1989; 2: 464-9.

31 Fattal B. Infectious disease morbidity in kibbutzim Harefuah 1988; 115; 111-5.

32 Eliakim M. Epidemiology of viral hepatitis in Israel, 1978 Isr F med Sci 1979; 15: 248-55.

33 Lange W. Mashi KN. Epidemiologic and economic importance of hepatitis $\mathbf{B}$ in the Federal Republic of Germany. Postgrad Med f 1987; 63 (suppl 2): 21-6.

34 Bar Shany S, Naggan L. HBsAg and anti-HBs among Israeli blood donors. Vox Sang 1976; 30: 191-9.

35 Sandler SG, Nath N, Biger Y. Seroepidemiology of hepatitis B virus in Israel. Am $\mathcal{F}$ Epidemiol 1977; 106: 76-82.

36 Yodfat Y, London WT, Whitford P, et al. A seroepidemiological study of hepatitis $\mathrm{B}$ in rural areas in Israel. Am f Epidemiol 1982; 116 456-62.

37 Egoz N, Naggan L, Feingold A, Bar-Shanay S. Prevalence of hepatitis $\mathrm{B}$ antigen among army inductees. $I s r \mathcal{F} \mathrm{Med} S \mathrm{C}$ 1975; 1 : 777-80.

38 Centers for Disease Control. Hepatitis surveillance. Rockville: US Dept of Health and Human Services. Report number 52, 1989: 17

39 Stewart JS, Farrow LJ, Clifford RE, et al. Three year survey of viral hepatitis in West London. $Q \mathcal{f}$ Med 1978; 47: 365-84.

40 Polakoff S, Tillet HE. Acute viral hepatitis B: laboratory reports 1975-9. $B M \mathcal{F}$ 1982; 284: 1881-2.

41 Matskin H. Epidemiologic features of acute viral hepatitis among the Israeli Defence Forces, 1977-1983. F Infec 1987; 14: 271-8.

42 Ben-Porath E, Hornstein L, Zeldis J, et al. Hepatitis B virus infection and liver Disease in Ethiopian immigrants to Israel. Hepatology 1986; 6: 662-6.

43 Shalev E, Bassan H M. Viral hepatitis during pregnancy in Israel. Int f Gynecol Obstet 1982; 20: 73-8.

44 Centers for Disease Control. Hepatitis surveillance. Rockville: US Dept of Health and Human Services. Report number 52, 1989: 22.

45 Shalit M. Tur-Kaspa R, Adler R, et al. Non-A, non-B hepatitis not following transfusion. A study of hospital patients in Jerusalem. Isr $\mathcal{F}$ Med Sci 1982; 18: 986-7.

46 Central Bureau of Statistics. Hospitalizations 1979. Special series No 803. Jerusalem: Central Bureau of Statistics, 1987.

47 Central Bureau of Statistics. Hospitalizations 1976. Special series No 708. Jerusalem: Central Bureau of Statistics, 1983.

48 Eshel E, Bassan HM. Viral hepatitis Types B and Non-B. Harefuah 1979; 96: 180-2.

49 Tolsma DD, Bryan JA. The economic impact of vira hepatitis in the United States. Public Health Rep 1976; 91 349-53.

50 Adler MW, Belsey EM, McCutchan JA, Mindel A. Should homosexuals be vaccinated against hepatitis B virus? Cost and benefit assessment. $B M \mathscr{F} 1983 ; 286: 1621-4$.

51 Ben-Porath E, Enat R, Gruia M, Satinger Y. Etiology of acute viral hepatitis in Israel. Harefuah 1985; 108: 583-5.

52 Sandler SG, Shouval D, Marcus M, Eliakim M. Type B and non-B viral hepatitis in Jerusalem. Bull WHO 1976; 54: non-B

53 Alkan M, Fainaru $M$. Etiology of hepatitis $B$ antigen positive acute viral hepatitis. Harefuah 1973; 85: 255-6.

54 Krausz Y, Melamed S, Sandler SG, Eliakim M. A comparative study of hepatitis $B$ and non-B in hospitalized adults in an endemic area. Isr $\mathcal{F}$ Med Sci 1977; 13: 9-14.

5 De Virgilis S, Frau D, Sanna G, et al. Perinatal hepatitis B virus detection by hepatitis $\mathrm{B}$ virus DNA analysis. Arch Dis Child 1985; 60: 56-8.

56 Greenfield C, Osidiana V, Karayiannis $\mathrm{P}$, et al. Perinatal transmission of hepatitis $B$ virus in Kenya: its relation to the presence of serum HBV-DNA and anti-HBe in the mother.

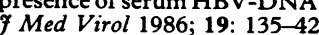

57 Hwang LU, Roggendorf $M$, Beasley RP, Deinhardt $F$. Perinatal transmission of hepatitis B virus; role of maternal $\mathrm{HBeAg}$ and anti-HBc IgM. $\mathcal{F}$ Med Virol 1985; 15: 265-9.

58 Naggan L, Sarov B, Bar-Shany S. Modes of transmission of hepatitis B infection in newborns and infants within the
family. (Abstract) In: Szmuness W, et al, eds. Viral hepatitis. Proceedings of the International Symposium on Viral Hepatitis, New York, 1981: 670-1.

59 Naggan L. Bar-Shany S. Shmuelewitz D, et al. Prevalence of hepatitis $\mathrm{B}$ markers (HBsAg and $\mathrm{HBsAb}$ ) in women hepatitis B markers (HBsAg and HBsAb) in women
screened at time of delivery. Isr $\mathcal{M}$ Med Sci 1980; 16: 347-50.

60 Shouval D. Tur-Kaspa R, Adler R, et al. Study of 90 hepatitis B surface antigen carriers in Israel. Isr $\widetilde{J}$ Med $S c i$ $1981 ; 17 ; 407-12$. 
61 Franks AL, Berg CJ, Kane MA, et al. Hepatitis B virus infection among children born in the United States to Southeast Asian Refugees. N Engl f Med 1989; 321: 1301-5.

62 Tur-Kaspa R, Keshet E, Eliakim M, Shouval D. Detection and characteristics of hepatitis B virus DNA in serum of $\mathrm{HBe}$ antigen negative $\mathrm{HBsAg}$ carriers. $\mathcal{F}$ Med Virol 1986; 14: 17-26.

63 Central Bureau of Statistics. Monthly Bulletin of Statistics, Vol 41, No 8. Jerusalem: Central Bureau of Statistics, 1990.

64 Stevens CE, Toy P, Tong MJ, et al. Perinatal hepatitis B virus transmission in the United States: Prevention by passive-active immunization. $\mathcal{H} A M A$ 1985; 253: 1740-5.

65 Wong WCV, Ip HMH, Reesnik HW, et al. Prevention of the HBsAg carrier status in newborn infants in mothers who HBsAg carrier status in newborn infants in mothers who administration of hepatitis $B$ vaccine and and hepatitis B administration of hepatitis $B$ vaccine and and hepatitis $B$ immune globulin: double-blind random

controlled study. Lancet 1984; i: 9821-36.
66 Beasley RP, Hwang LY, Lin CC, et al. Hepatitis B immune globulin (HBIG) efficacy in the interruption of perinatal transmission of hepatitis B virus carrier state. Lancet 1981 ii: $383-93$.

67 Beasley RP, Hwang LY, Stevens CE, et al. Hepatitis B immune gobulin (HBIG) for prevention of perinatal transmission of the HBV carrier state: final report of transmission of the HBV carrier state: final report of Hepatology 1983; 3: 135-41.

68 Schwartz JS. Hepatitis B vaccine. Ann Intern Med 1984; 100 149-50.

69 Davidson M, Krugman S. Recombinant yeast hepatitis B vaccine compared with plasma dried vaccine: immunogenicity and effect of a booster dose. $\mathcal{F}$ Infect 1986 13 (suppl A): 31-8.

70 Barbara JAJ, Howell DR, Contreras M, et al. Indicators for hepatitis B immunoglobulin for neonates of $\mathrm{HBsAg}$ carrie mothers. BMF 1984; 289: 880

71 Mariner E, Barrios V, Larouze B, et al. Lack of perinatal transmission of hepatitis B virus infection in Senegal, West Africa. Pediatrics 1985 ; 106: 843-9.
72 Szmuness W, Stevens CE, Zang EA, et al. A controlled clinical trial of the efficacy of the hepatitis $B$ vaccine: a final clinical trial of the efficacy of the hepa
report. Hepatology $1981 ; 1: 377-85$.

73 Jonsson B. Cost-benefit analysis of hepatitis B vaccination. Postgrad Med f 1987; 63 (suppl 2): 27-32.

74 Shaw FE, Graham DJ, Guess HA, et al. Postmarketing surveillance for neurologic adverse events reported after surveillance for neurologic adverse events reported after

75 Thiebault GE, Mulley AG, Barnett GO, et al. Medical intensive care: indications, interventions and outcomes. $N$ Eng $f$ Med 1980; 302: 938-42.

76 Dienstag JL, Watkins E, Hinckl CA. Recombinant yeast hepatitis B vaccine; immunogenicity and safety. Hepatology 1984; 4: 1077-90.

77 Manufacturer's instructions for use of H-B-VAX II (Hepatitis B vaccine-recombinant), H4769/75. Haarlem, The Netherlands: Merick Sharp and Dohme.

78 Central Bureau of Statistics. Statistical abstract of Israel 1989. Jerusalem: Central Bureau of Statistics, 1989.

79 Lahaye D, Strauss P, Baleux C, Van Ganse W. Cost-benefit analysis of hepatitis B vaccination. Lancet 1987; ii: 441-3.

80 Dudley FJ, Scheur PJ, Sherlock S. Natural history of hepatitis associated antigen-positive chronic liver disease. Lancet 1972; ii: 1388-93.

81 Hadziyannis SJ. Chronic viral hepatitis. Clin Gasroenterol 1974; 3: 391-408.

82 Umenai T, Suzuki H, Hepatitis B vaccination. World Health November 1989: 24-5.

83 Centers for Disease Control. Changing patterns of groups at high risk for hepatitis B in the United States. MMWR 1988; 37: 429-37.

84 Martini GA, Strohmeyer G. Posthepatitis syndromes. Clin Gastroenterol 1974; 3: 377-90.

$85 \mathrm{Krugman} \mathrm{S}$. The newly licensed hepatitis $\mathrm{B}$ vaccine. $7 A M A$ 1982; 247: 2012-5.

86 Zajac BA, West DJ, McAleer WJ, Scolnick EM. Overview of clinical studies with HBV vaccine made by recombinant DNA. F Infect 1986; 13 (suppl A): 39-45.

87 Chemtob D, Fassberg J, Kalka I, et al. Prevention strategy of hepatitis B virus infection among the Ethiopian community in Israel. Isr f Med Sci 1991; 27: 273-7. 